\title{
High Efficiency Operational Reserve by SOFC for the Effective Grid Integration of Variable Renewable Energies
}

\author{
Fumihiko Yoshiba ${ }^{1, *}$, Tohru Yamamoto $^{1}$, Hiroshi Morita ${ }^{1}$, Yuji Hanai ${ }^{1}$, Isamu Watanabe ${ }^{1}$, \\ and Yoshihiro Mugikura ${ }^{1}$ \\ ${ }^{1}$ Central Research Institute of Electric Power Industry, 2-6-1 Nagasaka, Yokosuka, 240-019 Japan
}

\begin{abstract}
For an effective grid integration of a large share of intermittent renewable energy sources such as a photovoltaic and a wind power, the flexible operation of the centralized or decentralized thermal power plants are required as a control reserve of demandsupply balance (frequency control). It is cleared that the Solid Oxide Fuel Cell and Gas Turbine (SOFC/GT) with additional air compressor system offers high efficiency in the wide range load operation. The efficiency- load ratio curve of the Gas Turbine Combined Cycle (GTCC) and SOFC/GT with air compressor system are applied to the secondary control reserve (SCR) operation units, and the daily schedule of power units in the modelled power grid is calculated. Since the efficiency at low load is high in SOFC/GT with air compressor system, the total fuel cost of the modelled power grid diminishes in the case that the SOFC/GT with air compressor system is operated at low load as a load frequency control (LFC) unit for the SCR.
\end{abstract}

\section{Introduction}

Since the power supply from renewable energy source such as a solar or a wind power has a fluctuation and an intermittency, the introduction of the large amount of renewable energy is expected to lead to a lack of frequency controllability and an excess power supply to an electricity grid. To stabilize the frequency and demandsupply balance (frequency) of the electricity grid, a load following operation at partial load is required for the thermal power plants, which is responsible for their low efficiency. As well as the attempts to upgrade the efficiency at rated power of thermal power plants, the efficiency improvement is required at partial load during the high share of renewable energies.

Because the cell voltage of fuel cells is high at low current density conditions, the fuel cell power systems are believed to achieve high efficiency at partial load operation. In high temperature fuel cell such as Solid Oxide Fuel Cell (SOFC) systems, however, the efficiency at partial load operation should be considered with the relation between current density and operating temperature. In this paper, the efficiency of the SOFC and gas turbine hybrid system (SOFC/GT) is calculated at partial load. By supposing an introduction of the SOFC/GT system to an electricity power grid, the advantage of the high

* Corresponding author: yoshiba@ criepi.denken.or.jp 
efficiency at partial load is discussed in terms of fuel consumption of the power plants lineupped in the electrical power grid.

\section{Wide range high efficiency system by SOFC/GT}

\subsection{Cell voltage in partial load of SOFC}

In Fig. 1, the relation between the cell voltage and the current density of an SOFC is described schematically. The cell voltage increases inversely proportional to the current density when SOFC is operated at constant temperature; this is fuel cell's basic property observed in bench scale tests (dotted line). When the SOFC is operated in the system, the cell temperature of SOFC decreases by heat loss during the partial load operation, thus, the cell voltage drops in the partial load condition which is responsible to decrease the cell voltage. The SOFC power system, consequently, has a peak efficiency at medium load [1].

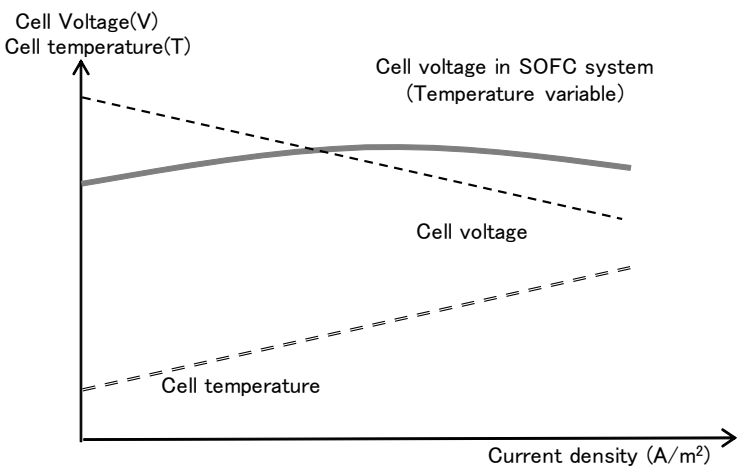

Fig. 1. Schematic relation between current density and cell voltage.

\subsection{Relation between current density and cell voltage}

The relation between the cell voltage and current density is determined as expressed in equation (1). V (V) and E (V) are the cell voltage and Nernst voltage, respectively, $R_{\mathrm{ir}}, \mathrm{R}_{\mathrm{a}}$, $\mathrm{R}_{\mathrm{c}}\left(\Omega \mathrm{m}^{2}\right)$ represent the cell resistance, and $\mathrm{j}$ refers to the current density $\left(\mathrm{A} / \mathrm{m}^{2}\right)$. The Nernst voltage and the cell resistance are regulated as in equation (2). Here, $\mathrm{E}^{0}, \mathrm{R}, \mathrm{T}, \mathrm{F}, \mathrm{p}_{\mathrm{i}}$, describe the standard electro-motive force $(\mathrm{V})$, universal gas constant $(\mathrm{kJ} / \mathrm{mol} \mathrm{K})$, cell temperature $(\mathrm{K})$, Faraday's constant $(\mathrm{C} / \mathrm{mol})$ and partial pressure of the gas composition $\mathrm{i}$ (atm, subscript a and c refer to anode and cathode), respectively.

$$
\mathrm{V}=\mathrm{E}-\eta_{\mathrm{ne}}-\left(\mathrm{R}_{\mathrm{ir}}+\mathrm{R}_{\mathrm{a}}+\mathrm{R}_{\mathrm{c}}\right) \mathrm{j} \quad \mathrm{E}=\mathrm{E}^{0}+\mathrm{RT} / 2 \mathrm{~F} \ln \left(\mathrm{P}_{\mathrm{H} 2, \mathrm{a}} \mathrm{P}_{\mathrm{O} 2, \mathrm{c}}{ }^{1 / 2} / \mathrm{P}_{\mathrm{H} 2 \mathrm{O}, \mathrm{a}}\right)
$$

The internal resistance $\left(\Omega \mathrm{m}^{2}\right)$ and the anode $\left(\Omega \mathrm{m}^{2} \mathrm{~atm}\right)$ and cathode $\left(\Omega \mathrm{m}^{2} \mathrm{~atm}^{0.5}\right)$ reaction resistance are expressed as follows:

$\mathrm{R}_{\mathrm{ir}}=\mathrm{A}_{\mathrm{ir}} \exp \left(\Delta \mathrm{H}_{\mathrm{ir}} / \mathrm{R} \mathrm{T}\right) \mathrm{R}_{\mathrm{a}}=\mathrm{A}_{\mathrm{a}} \exp \left(\Delta \mathrm{H}_{\mathrm{a}} / \mathrm{R} \mathrm{T}\right) \mathrm{P}_{\mathrm{H} 2, \mathrm{a}}{ }^{-1} \mathrm{R}_{\mathrm{c}}=\mathrm{A}_{\mathrm{c}} \exp \left(\Delta \mathrm{H}_{\mathrm{c}} / \mathrm{R} \mathrm{T}\right) \mathrm{P}_{\mathrm{o} 2, \mathrm{c}}{ }^{-0.5}$

$\mathrm{A}_{\text {ir }}\left(\Omega \mathrm{m}^{2}\right), \mathrm{A}_{\mathrm{a}}\left(\Omega \mathrm{m}^{2} \mathrm{~atm}\right), \mathrm{A}_{\mathrm{c}}\left(\Omega \mathrm{m}^{2} \mathrm{~atm}^{0.5}\right)$ refer to the frequency coefficient of the internal resistance and the anode and cathode reaction resistance, $\Delta \mathrm{H}_{\mathrm{ir}}\left(\mathrm{kJ} \mathrm{mol}^{-1}\right), \Delta \mathrm{H}_{\mathrm{a}}\left(\mathrm{kJ} \mathrm{mol}^{-1}\right)$, $\Delta \mathrm{H}_{\mathrm{c}}\left(\mathrm{kJ} \mathrm{mol}^{-1}\right)$ give an indication of the activation energy, respectively. By dividing the SOFC cell into control volumes and applying the cell performance Eqs. (1) - (5) to these volumes, the electrical output power and the current density distribution in the SOFC cell can be calculated. 


\subsection{System configuration of the SOFC/GT with air compressor}

The configuration of SOFC/GT with air compressor system is described in Fig.2. One of the SOFC module (SOFC module 1), which has an SOFC stack, a reformer, a combustor, and an air preheater, is connected to the gas turbine, while the other SOFC module (SOFC module 2) is coupled with the air compressor driven by the electric motor. In each SOFC module, the natural gas is mixed with the exhausted anode gas in an ejector before entering the reformer, and the hydrogen enriched gas flows into the anode gas channel of the SOFCs. The cathode gas (air) of the SOFC module 1 is supplied from the compressor of gas turbine, whereas the cathode gas of the SOFC module 2 is provided by the individual air compressor. The exhausted anode and cathode gas are combusted in the combustor of the SOFC module to heat up the cathode air in the air preheater. The outlet gas of SOFC module 1 and 2 are mixed in the gas mixer and introduced to the expander (Turbine) of the gas turbine.

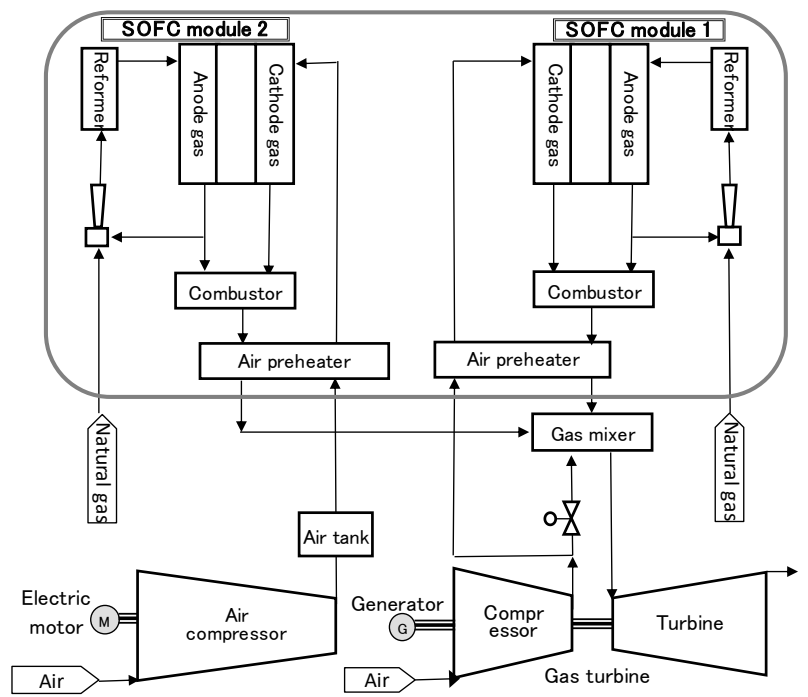

Fig. 2. Configuration of the SFOC/GT with air compressor system.

\subsection{Efficiency Calculation}

In table 1, the operating conditions applied in the calculation procedure of the system efficiency is listed. The heat loss of the SOFC module is set high because the power density $(\mathrm{kW} / \mathrm{l})$ of SOFCs are relatively lower than in the case of gas turbines or steam turbines. The calculated system performance of SOFC/GT with air compressor system is shown in table 2, at the operating current density of $3500 \mathrm{~A} / \mathrm{m}^{2}$. Because the SOFC is operated at high pressure $(1.2 \mathrm{MPa})$, the cell voltage is high $(774 \mathrm{mV})$ which is responsible for the high efficiency of the system.

In order to maintain the temperature of the SOFC module and to keep the gas turbine pressure, the sufficient energy input in the SOFC module is required, thus, the current density of the SOFC module 1 is fixed at $3500 \mathrm{~A} / \mathrm{m}^{2}$ except the very low load operation. The power output is varied mainly by changing the current density of the SOFC module 2 (current density is changed from $1500 \mathrm{~A} / \mathrm{m}^{2}$ to $6500 \mathrm{~A} / \mathrm{m}^{2}$ ). In Fig. 3, the calculated system efficiency of the SOFC/GT with air compressor system is related to the power output. The maximum efficiency is found at the medium load condition, while the efficiency decreases during the low load and high load conditions. 
Table 1. Operating conditions of the SOFC modules, the Gas turbine, ant the air compressor.

Fuel gas composition (mol\%)

Heating value of fuel $\left(\mathrm{MJ} / \mathrm{m}^{3} \mathrm{~N}\right)$

Heat source of reformer

$\mathrm{CH}_{4} / \mathrm{C}_{2} \mathrm{H}_{6} / \mathrm{C}_{3} \mathrm{H}_{8} / \mathrm{C}_{4} \mathrm{H}_{10} / \mathrm{C}_{5} \mathrm{H}_{12} / \mathrm{N}_{2}=89.8 / 5.39 / 4.27 / 0.5 / 0.01 / 0.03$

44.3 (High Heating Value, HHV), 40.8 (Low Heating Value, LHV)

Anode exhausted gas

Fuel recirculation method and fuel utilization

Operating pressure and current density

Temperature range of SOFC

Heat loss of SOFC module

Inverter efficiency and auxiliary loss

Isentropic efficiency
Ejector, $80 \%$ (of input fuel base)

1.2MPa, $1,500-6,500 \mathrm{~A} / \mathrm{m}^{2}$

$720-950{ }^{\circ} \mathrm{C}$ (Maximum temperature difference $=100^{\circ} \mathrm{C}$ )

$5.7 \%$ of input fuel enthalpy

$95 \%, 2 \%$ (of input fuel enthalpy)

90\%/88\% (Compressor/expander of GT), $90 \%$ (air compressor)

Table 2. Calculated performance of SOFC/GT with air compressor system (At maximum efficiency).

Current density

SOFC temperature

SOFC cell voltage

Air utilization

SOFC power (AC)

Gas turbine inlet temperature/turbine power(AC)

Auxiliary power consumption

System power output / fuel energy input

Efficiency
$3500 \mathrm{~A} / \mathrm{m}^{2}$ (Current density of module 1 and 2 )

$850-900^{\circ} \mathrm{C}\left(\Delta \mathrm{T}=50^{\circ} \mathrm{C}\right)$

$774 \mathrm{mV}$

$19.3 \%$

$30,872 \mathrm{~kW}$

$1,040^{\circ} \mathrm{C} / 2,913 \mathrm{~kW}$

$1,211 \mathrm{~kW}$

$32,574 \mathrm{~kW} / 60,543 \mathrm{~kW}$

$55.8 \%$ (HHV, Gross), $53.8 \%$ (HHV, Net)

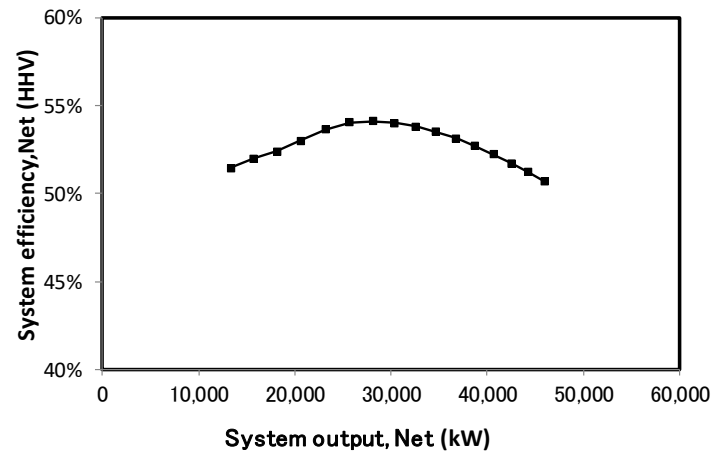

Fig. 3. Calculated efficiency V.S. power output of SOFC/GT with air compressor system.

\section{Contribution of SOFC in power grid}

\subsection{Efficiency of GTCC and SOFC/GT with air compressor system}

The frequency of the electric power grid is controlled mainly by the pumped hydro and thermal power plants. During the large introduction of intermittent renewable energies, such as wind or photovoltaic power, the thermal power plants are requested to control the frequency under at low load conditions, which is responsible for its low efficiency. When the wide range high efficiency system (SOFC/GT with air compressor) described in this paper replaces a frequency controllable thermal power unit (GTCC), there is a possibility to minimize the fuel consumption required to maintain the stability of the frequency.

For the purpose to estimate the effect of the replacement of controllable thermal power unit by the SOFC/GT+ air compressor system, the system efficiency of GTCC is compared. The partial load efficiency of SOFC/GT with air compressor system and Gas Turbine Combined Cycle (GTCC) are compared in Fig. 4. Here, the efficiency of GTCC at the rated power (at $100 \%$ load) is supposed to be the same value $(53.8 \% \mathrm{HHV}$ ) as the maximum efficiency of SOFC/GT with air compressor system (at 55\% partial load). 


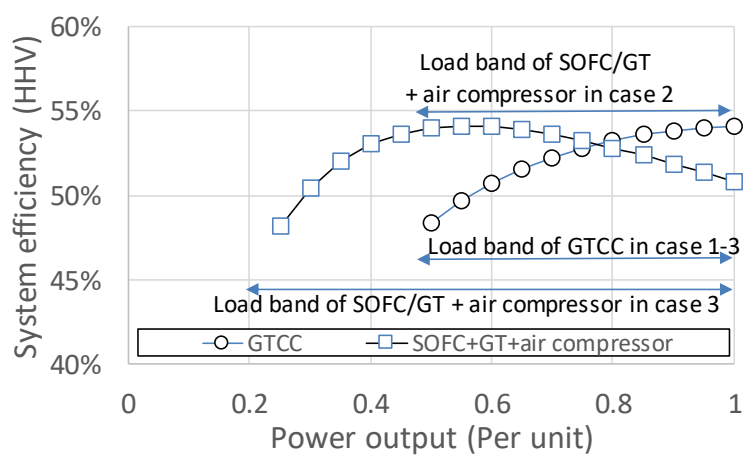

Fig. 4. Efficiency curve versus power output of GTCC and SOFC/GT with air compressor system.

\subsection{Power grid model and calculation case description}

The Automatic Generation Control (AGC30) model developed by Institute of Elecrtrical Engineers of Japan (IEEJ) is applied in the daily schedule of the power unit analysis [2,3]. The AGC30 model aims to provide common models and a platform for simulation studies on automatic generation control including speed governing for the primary control reserve, load frequency control (LFC) for the Secondary Control Reserve (SCR), and economic load dispatch control (EDC) for the tertiary control reserve. The composition of power sources in the AGC30 model excluding the renewable power sources is numerized in Table 3.

Table 3. Power sources in AGC30 model. (total capacity is 22,500MW)

\begin{tabular}{llcl} 
Power Source & Capacity (MW) & Capacity ratio (\%) & \multicolumn{1}{c}{ The number of unit } \\
\hline Nuclear & 4,500 & 20 & 500MW- 3units, 1000MW- 3units \\
OIL & 4,225 & 19 & 250MW- 3units, 700MW- 4units \\
LNG(Steam cycle) & 2,700 & 12 & 200MW- 3units, 700MW- 3units \\
GTCC & 3,160 & 14 & 250MW- 10units \\
COAL & 3,600 & 16 & 700MW- 2units, 1000MW- 2units \\
Run-off-river & 3,415 & 15 & summation of all hydro power \\
Pumped hydro & 900 & 4 & 300MW- 3units \\
\hline
\end{tabular}

In the analysis of the daily schedule of the power units, three cases in Table 4 are assumed. In case 1 , two units of $250 \mathrm{MW}$ class GTCC are selected as the LFC units with the LFC range of $50-100 \%$, and one unit of Gas Steam unit (LNG steam cycle) works as the additional LFC unit, i.e. three units always cover the LFC capability. In case 2, the two GTCC units selected as LFC units in case 1 are substituted by the two units of SOFC/GT with air compressor system (LFC range of $50-100 \%$, same as GTCC); here, the capacity of $\mathrm{SOFC/GT}$ with air compressor system is enlarged to $250 \mathrm{MW}$ which is five times more than the capacity in Fig.3. In case 3, the LFC range of the SOFC/GT with air compressor system in case 2 is expanded to the load ratio of $25-100 \%$ (see Fig.4).

Table 4. LFC units selected for three cases.

Case 12 units of GTCC*, 1 unit of LNG-steam (Liquefied natural gas - steam cycle)

Case 22 units of SOFC/GT with air compressor*, 1 unit of LNG-steam

Case 32 units of SOFC/GT with air compressor (LFC range minimized)*, 1 unit of LNG-steam

\subsection{Daily schedule of power units and fuel costs}

The daily schedule of the power units of case 1 is illustrated in Fig. 5, and the fuel costs of the GTCC, the LNG-steam, and the coal power units in AGC30 model are compared for three cases in Fig. 6. In case 2, since two units of the SOFC/GT with air compressor 
system, which is operated at around $75 \%$ load with high efficiency, replaces the LFC capacity of LNG-steam units, the power of LNG-steam cycle units decreases (because the efficiency of the LNG-steam unit is low). As a result, the power increases in the GTCCs that are not substituted by SOFC/GT with air compressor system (there are 10 units of GTCC in the AGC30 model). In case 3, the LFC operation range of the SOFC/GT with air compressor system is expanded to lower load, thus, the power of the LNG-steam cycle unit decreases more than in the case 2 , while the power of the coal unit which has the lowest fuel cost increases The fuel cost of all the thermal power unit (total fuel cost) in the AGC 30 is the lowest in case 3 among three cases as compared in Fig. 6.

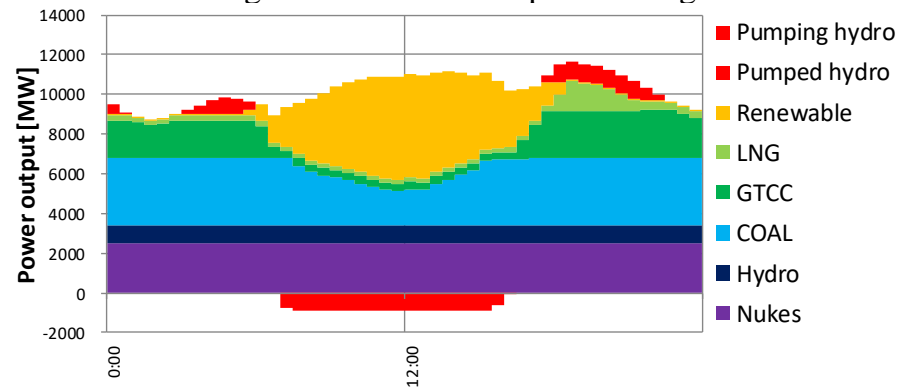

Fig. 5. The analysis result of daily schedule of power units (case 1, calculated for light demand day).

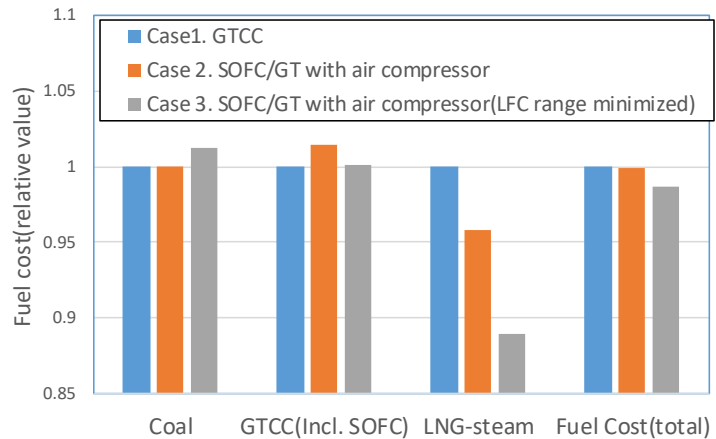

Fig. 6. Comparison of fuel cost of the thermal power units in AGC30 model for three cases.

*Fuel Cost(total): Fuel cost of all the thermal power unit.

\section{Conclusion}

The characteristics of the SOFC is reviewed from the point of view of the efficiency at partial load. It is cleared that the SOFC/GT with air compressor system offers high efficiency during the wide range load operation, which has a potential to provide high efficiency LFC operational reserve. The daily schedule of the power unit is calculated under the comparison of the efficiencies of the GTCCs and the SOFC/GT with air compressor systems. The total fuel cost of all the thermal power unit in AGC30 model is minimized in the case that two GTCC units are substituted by two low load operation units of SOFC/GT with air compressor systems.

\section{References}

1. F. Yoshiba, et al., The Journal of Fuel Cell Technology, 171 (2017)

2. Technical Report No.1386, The Institute of Electrical Engineers of Japan, Dec. (2016)

3. I. Watanabe, et al., CRIEPI Rep. No. R13013, (2014) 